\title{
IQTISHODUNA
}

IQTISHODUNA: Jurnal Ekonomi Islam

E-ISSN: 2443-0056, P-ISSN: 2252-5661

Accredited Number 21/E/KPT/2018

Volume 9 Issue 1, April 2020 | Page: 29-54

DOI: doi.org/10.36835/iqtishoduna.v9i1.468

\section{The Influence of Inflation, Exchange Rates, CAR and NPF to Stability of Islamic Banks in Indonesia Period 2015-2019}

\author{
Gumilang Budi L. P. ${ }^{1}$, Kusnendi ${ }^{2}$, Suci Aprilliani Utami ${ }^{3}$ \\ 1,2,3Departement of Islamic Economics and Finance, Faculty of Economic and Business \\ Education, Universitas Pendidikan Indonesia, Jl. Dr. Setiabudhi No. 229, Kota Bandung, \\ Indonesia \\ e-mail: ${ }^{1}$ gumilangbudi@student.upi.edu ${ }^{2}$ kusnendi@upi.edu ${ }^{3}$ suci.avril@upi.edu
}

\begin{abstract}
This study aims to see the extent of the influence of the level of Inflation (CPI), Exchange Rate (kurs), Capital Adequacy Ratio (CAR) and Non Performing Financing (NPF) on the Stability of Islamic Banks in Indonesia Period 2015-2019. To support research, we use the Vector Error Correction Model (VECM) methodology. VECM test results show that in the short term the significant effect on the level of stability are Kurs and CAR, with the direction of a negative relationship (reducing the level of stability). Meanwhile, in the long term the significant effect on the level of stability are inflation and Kurs with the direction of a negative relationship (reducing the level of stability). From the results of this study it can be concluded that the macroeconomic variables significantly affect the stability of Islamic banking, therefore the government has an important role in controlling macroeconomic turmoil to maintain Islamic banking stability. Besides that, the internal variables of the banking sector are considered to have no significant effect partially, therefore it is necessary to conduct further research with a variety of internal factors in the banking industry to prove their effects on the stability of Islamic banking
\end{abstract}

Keywords: inflation; exchange rates; CAR; NPF; islamic banks.

Abstrak: Penelitian ini bertujuan untuk melihat sejauh mana pengaruh dari tingkat Inflasi (IHK), Nilai Tukar (kurs), Capital Adequacy Ratio (CAR) dan Non Performing Financing (NPF) terhadap Stabilitas Bank Umum Syariah di Indonesia tahun 2015-2019. Untuk mendukung penelitian, kami menggunakan metodologi Vector Error Correction Model (VECM). Hasil pengujian VECM menunjukkan bahwa dalam jangka pendek yang berpengaruh signifikan terhadap tingkat stabilitas adalah Kurs dan CAR, dengan arah hubungan negatif (menurunkan tingkat stabilitas). Sedangkan, dalam jangka panjang yang berpengaruh signifikan terhadap tingkat stabilitas adalah inflasi dan Kurs dengan arah hubungan negatif (menurunkan tingkat stabilitas). Dari hasil penelitian ini dapat diambil kesimpulan bahwa variabel makroekonomi signifikan mempengaruhi stabilitas perbankan syariah, oleh karenanya pemerintah berperan penting dalam mengendalikan gejolak makroekonomi untuk menjaga stabilitas perbankan syariah. Disamping itu, variabel internal perbankan dinilai tidak siginifikan dalam mempengaruhi stabilitas secara parsial, oleh karenanya perlu dilakukan penelitian lanjutan dengan berbagai variasi faktor internal perbankan untuk membuktikan pengaruhnya terhadap stabilitas perbankan syariah.

Kata kunci: Stabilitas, Inflasi, KURS, CAR, NPF, Bank Umum Syariah, VECM.

\section{Introduction}

Instability or crisis is an adverse market condition and threatens economic performance that paralyzes the financial condition of households, companies and governments. Every instability always carries a large loss impact such as circumstances that disrupt the functions and operations of 
30 IQTISHODUNA: Jurnal Ekonomi Islam

Volume 9 Issue 1, April 2020

financial institutions. ${ }^{1}$ This can be reflected in the condition of Indonesia when experiencing economic and monetary crisis in 1997/1998. When the banking sector slumps, the economy slumps, and vice versa. $^{2}$

Can be seen in picture 1, financial stability in Indonesia has fluctuated (fluctuated) every year. Where, several times touched the red area that indicates the crisis suspected. The financial stability below is measured using the Financial System Stability Index (ISSK), which is one way to assess stability in the financial system. ${ }^{3}$ The following data ISSK:

\section{Picture 1.1 Indonesian Financial}

\section{Stability 2002-2018}

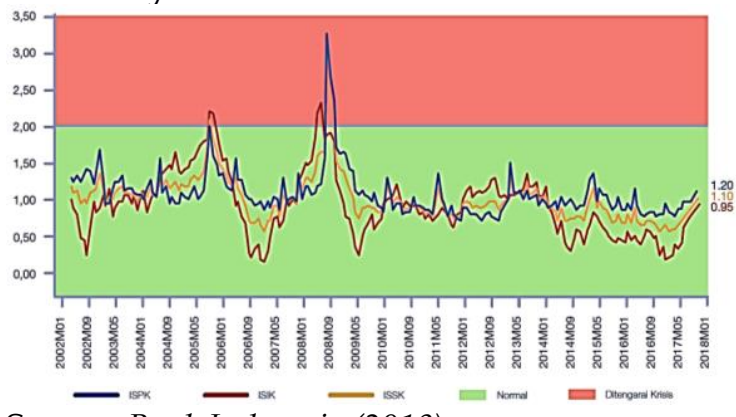

Source: Bank Indonesia (2018)

Based on the picture above it can be seen that the financial system in the first semester of 2018 in general experienced an increase in

${ }^{1}$ Suhartono. 2009. Peran Bank Sentral dalam Stabiitas Sistem Keuangan (SSK) dan Implementasi Jaring Pengaman Sektor Keuangan (JPSK). Jurnal Keuangan dan Perbankan, Vol. 13, No.3 , 518-533.

${ }^{2}$ Dwijayanthy, F., \& Naomi, P. 2009. Analisis Pengaruh Inflasi, BI Rate, dan Nilai Tukar Mata Uang terhadap Profitabilitas Bank Periode 2003-2007. Jurnal Karisma Vol. 3 No.2, 87-98.

${ }^{3}$ Widayatun Alfiana, V. W., \& Sianipar., A. S. 2016. Determinan Faktorfaktor yang Mempengaruhi Ketidakstabilan Keuangan di Indonesia. Widyatama, 1-30. pressure compared to the second semester of 2017. The increased pressure on financial system stability is reflected in an increase in the ISSK to 1.10 from 0.77 and the Systemic Banking Risk Index (IRSP) to 1.77. The increase in the SSK and IRSP indices was also influenced by the increased risk of global financial markets due to trade tensions between the United States (US) and a number of countries and the dynamics of uneven global economic growth. 4

The financial sector does have a role to assist in the re-allocation of resources and the flow of funds through payment system services, as well as increasing the capacity of the national economy. ${ }^{5}$ Therefore, stability is an important condition for maintaining sustainable and stable economic growth (Asfari, 2015). In addition, maintaining the stability of the banking industry is an important part that must be considered because the banking industry is one part that can affect the stability of the financial system in Indonesia. ${ }^{6}$

4Bank Indonesia. 2018, November 16. Penguatan Ketahanan Stabilitas Sistem Keuangan Mendorong Momentum Pertumbuhan. Kajian Stabilitas Keuangan No.31, September 2018, pp. 1-174.

${ }^{5}$ Gunadi, I., Taruna, A. A., \& Harun, C. A. 2015. Penggunaan Indeks Stabilitas Sistem Keuangan (ISSK) Dalam Pelaksanaan Surveilans Makroprudential. Working Paper Bank Indonesia, 1-55.

6Izazi, S. A., \& Waskito, A. 2014. Analisis Kompetisi Bank Umum Konvensiona dan Stabilitas Perbankan di Indonesia Periode 2004-2013: Sebuah Pendekatan Struktural dan Non Struktural. E-journal FE UI, 1-22. 
Banking stability according to Safitri is the ability of banks to carry out their intermediary functions properly and free from problems of financial difficulties. To measure stability in a bank, it can use the Zscore method, which is a risk measurement that is commonly used to determine the possibility of bank failure in running its business. ${ }^{7}$

Picture 1.2 Stability (Z-Score) of Sharia Commercial Banks in Indonesia in 2015-2019

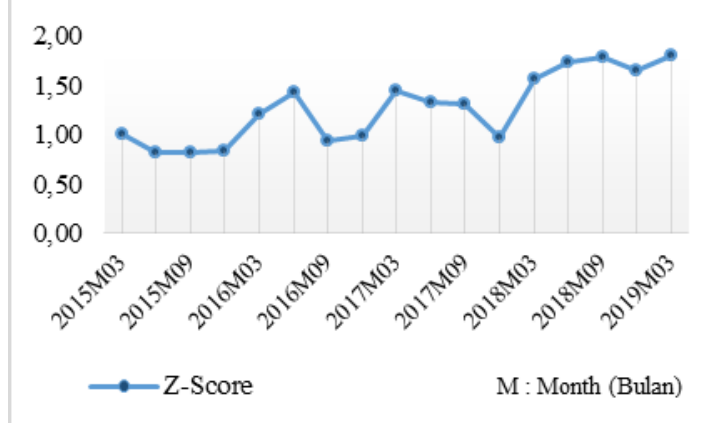

Source: The data is processed by researchers (2019)

Can be seen in Figure 1.2, the stability of Islamic commercial banks in Indonesia has fluctuated (fluctuated) over the past 4 years. Where, several times it has fallen sharply away from the number one or close to zero which reflects the stability that tends to be unstable.

The stability of the banking system is reflected by healthy banking conditions and the functioning of the banking intermediary function in mobilizing public deposits in the form of credit

\footnotetext{
7Safitri, T. R. 2018. Analisis Pengaruh Fakor Makroekonomi dan Faktor Fundamental Terhadap Stabilitas Perbankan Konvensional di Indonesia Tahun 2008-2017. Jurnal Ilmiah Mahasiswa FEB UNIVERSITAS BRAWIJAYA Vol 6, No 2: Semester genap 2017/2018, 1-13.
}

and financing to the business world. ${ }^{8}$ The higher Z-score, reflecting the higher bank stability. ${ }^{9}$ Where, a bank that has a Z-score close to zero means it tends to be unstable, a bank that has a Z-score far higher than zero means it has good stability and a bank that has a negative Z-score is a insolvent bank. ${ }^{10}$

There are several factors that can interfere with banking stability, namely internal and external factors. Internal factors related to all policies and decisions in regulating the bank's operational strategy. Meanwhile, external factors are risks outside of banking control which usually occur due to macroeconomic shocks. ${ }^{11}$ Suhartono also agreed, he stated in general the source of instability could be divided into two namely endogenous risk and exogenous risk. Exogenous risk is risk arising outside the financial sector, such as macroeconomic disruption or risk of events such as natural disasters. Endogenous risk is the risk that is within the financial sector itself such as from banks such as credit risk, market risk, and operational risk. ${ }^{12}$

\footnotetext{
${ }^{8}$ Ichsan, N., \& Akhiroh, M. 2017. Analisis Pengaruh Ekonomi Makro dan Stabilitas Perbankan Syariah terhadap Pembiayaan Produktif dan Konsumtif pada Perbankan Syariah di Indonesia Periode Januari 2010-Maret 2017. Jurnal Akses Vol.12 No.23, 68-83

${ }^{9}$ Wibowo, B. 2016. Stabilitas Bank, Tingkat Persaingan Antar Bank dan Diversifikasi Sumber Pendapatan: Analisis Per Kelompok Bank di Indonesia. Jurnal Manajemen Teknologi Vol.15 No.2, 172-195.

${ }^{10}$ Safitri. Ibid

11Safitri, Ibid.

${ }^{12}$ Suhartono. Ibid.
} 
32 IQTISHODUNA: Jurnal Ekonomi Islam Volume 9 Issue 1, April 2020

Based on research, there are those who say the stability of conventional banks is more stable as the research conducted by Altaee, Talo and Adam which concludes that Islamic banks have lower $\mathrm{z}$ scores and are less stable than conventional banks. In addition, conventional banks are more stable because their liquidity levels are higher. ${ }^{13}$ Liquidity, which is reflected by trust, still makes conventional banks superior to Islamic banks. ${ }^{14}$ Meanwhile, large Islamic banks are less stable than large conventional banks. In contrast, small Islamic banks are found to be more stable than small conventional banks. ${ }^{15}$

$\mathrm{n}$ addition, those that conclude that Islamic banks are more stable as research conducted by Elsa and Utami which states that conventional banking is more efficient and has better asset quality, however, there is no stability difference between the two. ${ }^{16}$ In fact, there is a tendency for Islamic

${ }^{13}$ Altaee, H. H., Talo, I. M., \& Adam., M. H. 2013. Testing the Financial Stability of Banks in GCC Countries: Pre and Post Financial Crisis. International Journal of Business and Social Research (IJBSR), Vol.3, No.4, 93-105.

14Myirandasari., B. 2015. Analisis Komparasi Stabilitas Perbankan Syariah dan Konvensional (Bank Umum Devisa Non Go Public di Indonesia). Brawijaya, 1-20.

15Wahid, M. A., \& Dar., H. 2016. Stability of Islamic versus Conventional Banks: A Malaysian Case. Jurnal Ekonomi Malaysia 50 (1), 111-132.

${ }^{16}$ Elsa, \& Utami., W. 2015. Studi Komparasi Efisiensi, Kualitas Aset dan Stabilitas pada Bank Umum Konvensional di Indonesia Periode 2010-2014. Jurnal Ilmu Ekonomi dan Sosial, Volume 4, Nomor 1, 104114. commercial banks to be more stable than conventional commercial banks because stability in Islamic banks is not determined by diversity in income like conventional banks. ${ }^{17}$

Financial stability is a topic that has always been developing and is becoming a concern of many people due to crises occurring at the national and international levels such as the 1997-1998 and 2008 financial crises other. ${ }^{18}$ In essence, research on financial stability that has been focused on banking institutions has been carried out, both at home and abroad. The conclusions produced differ, because the use of variations of variables, methods, samples, periods and stability index approaches are used. Most of the research was carried out using the Z-Score ROA stability approach, using the classification of macroeconomic and fundamental factors as influence variables and using the panel method because the sample is more than one bank.

Although there have been many studies on banking stability in Indonesia, there are still various variations in the use of influence factors, methods, samples and approaches that can be used. This of course will produce new trends, so further research is still relevant to do. Therefore, the authors are

17Rahim, S. R., \& Zakaria., R. H. 2013. Comparison on Stability Between Islamic and Conventional Banks in Malaysia. Journal of Islamic Economics, Banking and Finance, Vol.9 No.132, 131-149.

${ }^{18}$ Asfari, D. D. 2015. Analisis Financial Stress Indikator Sebagai Alat Ukur Stabilitas Sektor Keuangan Indonesia. Jurnal Bina Ekonomi Vol.19 No.1, 15-25. 
The Influence of Inflation, Exchange Rates, Car And Npf To

Stability of Islamic Banks In Indonesia Period 2015-2019

interested in conducting research on banking stability by focusing on Islamic Commercial Banks that use Z-Score ROA measurements, and are associated with factors that influence them, namely inflation, CAR and NPF exchange rates. This study is entitled "The Influence of Inflation, Exchange Rates, Car and NPF to Stability of Islamic Banks in Indonesia Period 2015-2019" using the Vector Error Correction Model (VECM) method in order to determine the extent of influence between these variables in the short and long term.

There are five research questions. First, what is the general description of the level of stability (Z-Score) of Islamic Commercial Banks, inflation (CPI), exchange rates (kurs), Capital Adequacy Ratio (CAR), Non Performing Financing (NPF). Second, the extent of the influence of the inflation rate $(\mathrm{IHK})$ on the stability (Z-Score) of Islamic Commercial Banks. Third, the extent of the effect of the exchange rate (KURS level) on the stability (Z-Score) of Islamic Commercial Banks. Fourth, the extent of the influence of the level of Capital Adequacy Ratio (CAR) on the stability (Z-Score) of Islamic Banks. Fifth, the extent of the influence of the level of Non Performing Financing (NPF) on the stability (Z-Score) of Islamic Commercial Banks.

Based on the research questions that have been presented, in general the objectives of this study are five. First, Knowing how the general picture of the level of stability (ZScore) of Sharia Commercial Banks, inflation (IHK), exchange rates (kurs), Capital Adequacy Ratio ( CAR), Non Performing Financing (NPF). Second, knowing the extent of the influence of the inflation rate (IHK) on the stability (Z-Score) of Islamic Banks. Third, knowing the extent of the effect of the exchange rate (KURS level) on the stability (Z-Score) of Islamic Commercial Banks. Fourth, find out the extent of the influence of the level of Capital Adequacy Ratio (CAR) on the stability (Z-Score) of Sharia Commercial Banks. Fifth, find out the extent of the influence of the level of Non Performing Financing (NPF) on the stability (Z-Score) of Islamic Commercial Banks.

The research hypothesis is four. First, inflation (IHK) has a negative influence on the stability of Islamic Commercial Banks (Z-Score). Second, the exchange rate (kurs) has a negative influence on the stability of Islamic Commercial Banks (Z-Score). Third, the Capital Adequacy Ratio (CAR) has a positive influence on the stability of Islamic Commercial Banks (Z-Score). Fourth, NonPerforming Financing (NPF) has a negative influence on the stability of Islamic Commercial Banks (Z-Score).

\section{LITERATURE REVIEW Islamic Bank}

In international terminology, Sharia banking is known as Islamic Banking or Interset-fee banking, which cannot be separated from the origin of the system, which is basically developed by combining worldly and religious issues. ${ }^{19}$

${ }^{19}$ Gifari, Handoko, \& Yani. 2015. Analisis Kinerja Perbankan Syariah di Indonesia dan Malaysia Dengan Pendekatan 
34 IQTISHODUNA: Jurnal Ekonomi Islam Volume 9 Issue 1, April 2020

Meanwhile, in the Qur'an the term bank is not explicitly mentioned, but if what is meant is something that has elements such as structure, management, functions, rights and obligations, then some of these terms are mentioned when discussing alms, religious meal, selling buy, maal (assets) that have certain functions and roles in economic activities. ${ }^{20}$

\section{Islamic Bank Stability}

Bank stability is the ability of banks to carry out their intermediary functions properly and free from problems of financial difficulties. ${ }^{21}$ Meanwhile, the stability of Sharia Commercial Banks can be interpreted as a picture of the ability of the stability of the Islamic banking financial system when exposed to internal and external shocks (Ichsan \& Akhiroh, 2017). This stability can be created from a financial system that can maintain the level of profit or net income with stable and sustainable growth (Supriyanto, 2015). In addition, the ability to manage public funds and create a healthy business cycle will encourage stability (Sitepu, 2015). So that a stable bank is able to assess and manage risk effectively and allocate resources efficiently, and can maintain business continuity if there is a sudden economic disruption. ${ }^{22}$

Maqashid Indeks. Jurnal Ekonomi dan Perbankan Syariah Vol.3 No.2, 47-66.

${ }^{20}$ Bombang, S. 2013. Prospek

Perbankan Syariah di Indonesia. Jurnal

Diskursus Islam Vol.1 No.2, 265-288.

${ }^{21}$ Elsa etc., Ibid

22Safitri etc, Ibid.
According to Ichsan and Akhiroh, to measure stability in a bank, the Z-score model can be used. Model Z - Score is a tool used to predict the level of bankruptcy of a company by calculating the value of several ratios and then included in a discriminant equation. ${ }^{23}$

Z-score is a proxy of the probability of bank failure by combining measures of bank profitability, leverage, and volatility of bank profit levels into a measure of bank stability. ${ }^{24}$ In essence, the Zscore is a risk measurement to determine the possibility of bank failure in running its business. ${ }^{25}$ Mathematically, banking stability using the ROA approach using a formula made by Boyd et al in a journal Yudaruddin can be calculated as follows: ${ }^{26}$

$Z-S$ core $=\frac{R O A+\frac{E q}{T A}}{S D_{R O A}}$

The explanation can be described as follows as contained in the journal (Wibowo, 2016):

Z-Score : Bank Stability

ROA : Return on Asset (the ability to make a profit)

Eq : Average total equity or bank capital

TA : Average total bank assets

SDROA: ROA volatility is calculated using the standard deviation of ROA

The higher Z-score, reflecting the higher bank stability (Wibowo,

${ }^{23}$ Ichsan, etc. Ibid.

24Wibowo, Ibid.

${ }^{25}$ Safitri etc, Ibid.

26Yudaruddin, R. 2014. Dampak Tingkat Konsentrasi terhadap Kinerja dan Stabilitas Perbankan di Indonesia Tahun 2003-2013. Jurnal Keuangan dan Perbankan Vol.18 No.2, 278-286. 
2016). Meanwhile, banks that have a negative Z-score are insolvent. Banks that have Zscore near zero tend to be unstable. While banks that have a Zscore are much higher than zero, they have good stability (Safitri T. R., 2018).

\section{Inflation}

Inflation is the tendency of prices to rise generally and continuously (Latumaerissa, 2017). An increase in the price of one or two items alone cannot be called inflation unless the increase is widespread (or results in a price increase) in other goods. ${ }^{27}$ Meanwhile, Dwijayanthy, and Naomi stated that inflation is a condition of a sharp increase in prices (absolute) continuously in a long period of time followed by a decline in the real (intrinsic) value of a country's currency. ${ }^{28}$ Inflation is considered a monetary phenomenon because there is a decline in the value of the monetary calculation unit of a commodity. Inflation is measured by the inflation rate, which is the rate of change from the general price level. ${ }^{29}$

A condition can be said to be inflation if there are three components. First, there is a tendency for price increases. Second, the price increases that occur are general in nature that are not only experienced by one or several commodities. Third, price increases

\footnotetext{
${ }^{27}$ Bank Indonesia. Ibid.

${ }^{28}$ Dwijayanthy, etc. Ibid.

${ }^{29}$ Karim, A. 2015. Ekonomi Makro Islami. Jakarta: PT Raja Grafindo Persada.
}

take place continuously, not only happening at one time. ${ }^{30}$

\section{Exchange Rate}

Exchange rate is the price at which a country's currency can be converted into another country's currency. Meanwhile, the price of one currency in the form of foreign currencies is called the exchange rate. ${ }^{31}$ Exchange rates according to Ekananda (2014) are the price of a country's currency relative to other countries' currencies that have an important role in spending decisions, because the exchange rate allows us to translate prices from various countries into the same language. Exchange rates are determined by the amount of demand and also the supply of a currency. If the exchange rate does not occur, the value of a currency can depreciate or appreciate. ${ }^{32}$

\section{Capital Adequacy Ratio (CAR)}

Capital Adequacy Ratio (CAR) is a ratio used to measure how far the assets of banks that use risk are financed from their own capital in addition to obtaining funds from sources outside the bank (Yusuf \& Sari, 2013). Noorani, Hermani, \& Saryadi (2014), added that CAR is a ratio that shows how far all bank assets that contain risks (investment credit, securities, bills at other banks) to be funded from the bank's own capital funds, in addition to

\footnotetext{
${ }^{30}$ Rahardja, P., \& Manurung, M. 2004. Pengantar Ilmu Ekonomi: Mikroekonomi dan Makroekonomi. Jakarta: Fakultas Ekonomi Universitas Indonesia.

${ }^{31}$ Dwijayanthy, etc. Ibid

${ }^{32}$ Safitri, etc. Ibid.
} 
obtaining funds from outside sources, such as public funds, loans (debt) and others.

The calculation of the bank's minimum capital requirement is based on Risk Weighted Assets (RWA). In accordance with the CAR ratio assessment based on DIR BI Decree No. 30/12 / KEP / DIR 30 April 1997, CAR at least $8 \%$. The CAR ratio calculation in accordance with Bank Indonesia standards is as follows:

\section{Non Performing Financing (NPF)}

CAR $=\frac{\text { MODAL }}{\text { Aktiva Tertimbang Menurut Resiko (ATMR) }}$

$\mathrm{n}$ Islamic banking, problematic financing is known as Non Performing Financing (NPF), which is broadly defined as a financing in which payments are stagnant and do not meet the minimum obligations that are set to be difficult to be paid or even cannot be collected ${ }^{33}$. Amin, Rafsanjani, and Mujib describe the factors causing problematic financing as follows: 34

a. Internal factors are factors that exist within the company itself, and the main factor that is most dominant is the managerial factor.

\footnotetext{
${ }^{33}$ Mulyaningsih, S., \& Fakhruddin, I. 2016. Pengaruh Non Performing Financing Pembiayaan Mudharabah dan Non Performing Financing Pembiayaan Musyarakah Terhadap Profabilitas Pada Bank Umum Syariah di Indonesia. Jurnal Manajemen dan Bisnis MEDIA EKONOMI Volume XVI, No.1, 196-206.

${ }^{34}$ Amin, R., Rafsanjani, H., \& Mujib, A. 2017. Faktor-Faktor Yang Mempengaruhi Non Performing FInancing: Studi Kasus Pada Bank BPR Syariah di Indonesia. Jurnal Masharif al-Syariah: Jurnal Ekonomi dan Perbankan Syariah, 1-19.
}

b. External factors are factors that are outside the control of the company's management, such as natural disasters, wars, changes in economic and trade conditions, technological changes, etc.

The current NPL / NPF allowed by Bank Indonesia is a maximum of $5 \%$. If the NPL / NPF exceeds 5\%, it will affect the rating of the Bank's Soundness, and will also have an impact on the reputation of the bank itself. ${ }^{35}$ Calculation of NPF can be seen susing the following method:

$$
N P F=\frac{\text { Pembiayaan Bermasalah }}{\text { Total Pembiayaan }} x 100 \%
$$

\section{RESEARCH METHODS}

The research object contains research variables along with the characteristics or elements to be studied, the study population, research samples and research sites. In essence, the object of research includes what, who, where, when (Suryana, 2010). This research is focused on the influence of four variables that affect the stability of Islamic banking, namely the inflation variable (CPI), the exchange rate (exchange rate), the capital adequacy ratio (CAR) and the ratio of problem financing or Non Performing Financing (NPF). The subject in this study is the stability of Islamic Commercial Banks (BUS) in Indonesia. This study uses monthly data from January 2015 to March 2019 taken from the official website of the Financial Services Authority (OJK).

${ }^{35}$ Safitri, etc. Ibid 
The method used in this study is a quantitative descriptive method with a causal relationship (causality). Descriptive research is research designed to describe research subjects in an accurate way. In addition, quantitative research is research with the process of finding knowledge that uses data in the form of numbers as a means of analyzing. ${ }^{36}$ Meanwhile, causality research is research research that aims to obtain proof of causal relationships (Jiwandono, 2014).

The research design is a clear depiction of the relationship between variables, data collection, and data analysis, so that the relationship between variables is illustrated, how the data is and measuring it. ${ }^{37}$ The design of this study is an explanatory design that aims to explain the relationship between two or more variables. ${ }^{38}$ In this study there are five variables that are thought to be interconnected or influencing each other.

Data analysis techniques in this study were carried out through a series of stages of VAR / VECM analysis testing. VAR / VECM is a time series method that is often used in research, especially in economics. This study uses the VAR / VECM method because several advantages are deemed suitable for use, namely simpler where there is no need to separate independent and bound variables, better estimation results

\footnotetext{
36Kuntjotjo. 2009. Metodologi Penelitian. Kediri: Ebekunt.

37Kuntjotjo. Ibid

38Silalahi, U. 2012. Metode Penelitian Sosial. Bandung: Refika Aditama.
}

which can be estimated with both long and short time periods, suitable in time series data that illustrates economic fluctuations, as well as being suitable for macroeconomic issues whose effects require a certain grace period (lag). ${ }^{39}$

The data analysis technique used in this study was VECM analysis using the Eviews 8 software tool. The initial step taken was to test the data with stationarity, stability and cointegration test. Do not forget to do the steps to determine the optimum lag. Furthermore, the model can be tested for effect through the Engel-Granger and VECM causality test. Which in turn can be predicted by means of the Impulse Response Function (IRF) and Forecast Error Variance Decomposition (FEVD) tests.

\section{RESEARCH RESULT AND DISCUSSION \\ Stationarity Test}

In this study, the stationary test uses the ADF unit root test, because this unit root test is very popular and widely used (Ekananda, 2015). If the absolute value of $\mathrm{t}$-ADF is smaller than the MacKinnon critical values or the probability value (P-Value) is less than 0.05 then the data is stationary at the real level of five percent (at its level). But if the data is not stationary at the level, then the data must be derived at the first level (first difference). If it is not stationary at the first level, then the data must

\footnotetext{
${ }^{39}$ Basuki, A. T. 2018. Bahan Ajar: Aplikasi Model VAR dan VECM Dalam Ekonomi. Retrieved from EkonometrikBlog: ekonometrikblog.wordpress.com
} 
38 IQTISHODUNA: Jurnal Ekonomi Islam Volume 9 Issue 1, April 2020

be derived at the second level (second difference). ${ }^{40}$ Following are the results of the stationarity test for the ADF approach using the EViews 8.0 application:

\section{Table 4.1 Stationarity Test Results}

\begin{tabular}{|c|c|c|c|c|c|}
\hline $\begin{array}{l}\text { Varia } \\
\text { ble }\end{array}$ & $\begin{array}{l}\text { Unit } \\
\text { Roo } \\
t\end{array}$ & $\begin{array}{l}\text { ADF } \\
\text { Test } \\
\text { Statistic } \\
\text { s }\end{array}$ & $\begin{array}{l}\text { MacKinno } \\
n \text { Critical } \\
\text { Value } 5 \%\end{array}$ & $\begin{array}{l}\text { P- } \\
\text { Valu } \\
e\end{array}$ & $\begin{array}{l}\text { Infor } \\
\text { matio } \\
\text { n }\end{array}$ \\
\hline \multirow{3}{*}{$\begin{array}{l}\text { Stabil } \\
\text { ity }\end{array}$} & Level & $-\overline{3.628076}$ & -3.502373 & $\begin{array}{l}0.03 \\
74\end{array}$ & $\begin{array}{l}\text { Statio } \\
\text { nary }\end{array}$ \\
\hline & $\begin{array}{l}\text { First } \\
\text { Diffe } \\
\text { rence }\end{array}$ & $\begin{array}{l}- \\
9.296918\end{array}$ & -3.504330 & $\begin{array}{l}0.00 \\
00\end{array}$ & $\begin{array}{l}\text { Statio } \\
\text { nary }\end{array}$ \\
\hline & $\begin{array}{l}\text { Seco } \\
\text { nd } \\
\text { Diffe } \\
\text { rence } \\
\end{array}$ & $\begin{array}{l}- \\
10.61994\end{array}$ & -3.508508 & $\begin{array}{l}0.00 \\
00\end{array}$ & $\begin{array}{l}\text { Statio } \\
\text { nary }\end{array}$ \\
\hline \multirow{3}{*}{ IHK } & Level & $\begin{array}{l}- \\
1.841019\end{array}$ & -3.502373 & $\begin{array}{l}0.66 \\
97\end{array}$ & $\begin{array}{l}\text { Not } \\
\text { Statio } \\
\text { nary }\end{array}$ \\
\hline & $\begin{array}{l}\text { First } \\
\text { Diffe } \\
\text { rence }\end{array}$ & $\begin{array}{l}- \\
5.124746\end{array}$ & -3.506374 & $\begin{array}{l}0.00 \\
00\end{array}$ & $\begin{array}{l}\text { Statio } \\
\text { nary }\end{array}$ \\
\hline & $\begin{array}{l}\text { Seco } \\
\text { nd } \\
\text { Diffe } \\
\text { rence } \\
\end{array}$ & $\begin{array}{l}- \\
7.246495\end{array}$ & -3.510740 & $\begin{array}{l}0.00 \\
00\end{array}$ & $\begin{array}{l}\text { Statio } \\
\text { nary }\end{array}$ \\
\hline \multirow{3}{*}{$\begin{array}{l}\text { Excha } \\
\text { nge } \\
\text { Rate } \\
\text { (KUR } \\
\text { S) }\end{array}$} & Level & $\begin{array}{l}- \\
2.673329\end{array}$ & -3.502373 & $\begin{array}{l}0.25 \\
17\end{array}$ & $\begin{array}{l}\text { Not } \\
\text { Statio } \\
\text { nary }\end{array}$ \\
\hline & $\begin{array}{l}\text { First } \\
\text { Diffe } \\
\text { rence }\end{array}$ & $\begin{array}{l}- \\
8.425657\end{array}$ & -3.504330 & $\begin{array}{l}0.00 \\
00\end{array}$ & $\begin{array}{l}\text { Statio } \\
\text { nary }\end{array}$ \\
\hline & $\begin{array}{l}\text { Seco } \\
n d \\
\text { Diffe } \\
\text { rence } \\
\end{array}$ & $\begin{array}{l}- \\
7.762729\end{array}$ & -3.510740 & $\begin{array}{l}0.00 \\
00\end{array}$ & $\begin{array}{l}\text { Statio } \\
\text { nary }\end{array}$ \\
\hline \multirow{3}{*}{ CAR } & Level & $\begin{array}{l}- \\
2.167314\end{array}$ & -3.502373 & $\begin{array}{l}0.49 \\
67\end{array}$ & $\begin{array}{l}\text { Not } \\
\text { Statio } \\
\text { nary }\end{array}$ \\
\hline & $\begin{array}{l}\text { First } \\
\text { Diffe } \\
\text { rence }\end{array}$ & $\begin{array}{l}- \\
6.815802\end{array}$ & -3.504330 & $\begin{array}{l}0.00 \\
00\end{array}$ & $\begin{array}{l}\text { Statio } \\
\text { nary }\end{array}$ \\
\hline & $\begin{array}{l}\text { Seco } \\
n d \\
\text { Diffe } \\
\text { rence } \\
\end{array}$ & $\begin{array}{l}- \\
6.457506\end{array}$ & -3.513075 & $\begin{array}{l}0.00 \\
00\end{array}$ & $\begin{array}{l}\text { Statio } \\
\text { nary }\end{array}$ \\
\hline \multirow[t]{2}{*}{ NPF } & Level & $\begin{array}{l}- \\
3.049335\end{array}$ & -3.508508 & $\begin{array}{l}0.13 \\
03\end{array}$ & $\begin{array}{l}\text { Not } \\
\text { Statio } \\
\text { nary }\end{array}$ \\
\hline & $\begin{array}{l}\text { First } \\
\text { Diffe }\end{array}$ & - 3.240115 & -3.508508 & $\begin{array}{l}0.08 \\
92\end{array}$ & $\begin{array}{l}\text { Not } \\
\text { Statio }\end{array}$ \\
\hline
\end{tabular}

${ }^{40}$ Beik, I. S., \& Fatmawati, S. W. 2014. Pengaruh Indeks Harga Saham Syariah Internasional dan Variabel Makro Ekonomi Terhadap Jakarta Islamic Indeks. Al-Iqtishad, 155-178.

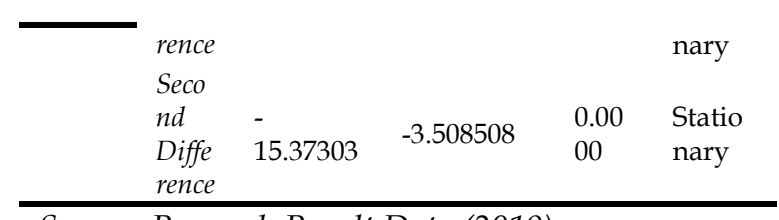

Source: Research Result Data (2019)

Based on Table 4.1, it can be seen that the ADF results at the level of only stability variables that are expressed stationary, besides all the variables declared not stationary because the P-value is greater than 0.05 and $\mathrm{t}$-ADF is greater than MacKinnon level of $5 \%$. Therefore it is necessary to do the ADF test on the first derivative (first difference). As a result, the Stability, CPI, Exchange Rate and CAR variables are stationary, but the NPF variable is not stationary. Then the ADF test was carried out again, on the second derivative (second difference). As a result, all variables (Stability, CPI, Exchange Rate, CAR and NPF) have been stationary in the second instance, because the P-value is smaller than 0.05 and $\mathrm{t}-\mathrm{ADF}$ is smaller than MacKinnon level of 5\%. So that other tests can be performed using data on the second derivative.

\section{Stability Test}

The optimal hose length chosen needs to be tested, whether the maximum hose length is stable or not. If all the roots of the polynomial function are in the unitcircle or the value of the AR roots is below one, then the model is considered stable so that it can produce valid predictions. ${ }^{41}$ Following are the results of stability testing using the EViews 8.0 application:

41Firdaus. 2011. Aplikasi Ekonometrika untuk Data Panel dan Time Series. Bogor: IPB Press. 
The Influence of Inflation, Exchange Rates, Car And Npf To

Stability of Islamic Banks In Indonesia Period 2015-2019

Table 4.2 Stabilty Test Results

\begin{tabular}{|c|c|c|}
\hline Root & & Modulus \\
\hline-0.748026 & \pm & \\
\hline $0.627416 \mathrm{i}$ & & 0.976316 \\
\hline-0.471119 & \pm & \\
\hline $0.845617 \mathrm{i}$ & & 0.967999 \\
\hline 0.705160 & \pm & \\
\hline $0.651396 \mathrm{i}$ & & 0.959984 \\
\hline-0.928679 & \pm & \\
\hline $0.230294 \mathrm{i}$ & & 0.956807 \\
\hline-0.956351 & & 0.956351 \\
\hline-0.027381 & \pm & \\
\hline $0.932732 \mathrm{i}$ & & 0.933134 \\
\hline 0.664915 & \pm & \\
\hline $0.648137 i$ & & 0.928544 \\
\hline-0.298006 & \pm & \\
\hline $0.872721 \mathrm{i}$ & & 0.922198 \\
\hline 0.271867 & \pm & \\
\hline $0.873959 \mathrm{i}$ & & 0.915268 \\
\hline-0.501756 & \pm & \\
\hline $0.754494 \mathrm{i}$ & & 0.906102 \\
\hline 0.428886 & \pm & \\
\hline $0.787608 \mathrm{i}$ & & 0.896811 \\
\hline-0.062554 & \pm & \\
\hline $0.847974 \mathrm{i}$ & & 0.850278 \\
\hline-0.704159 & \pm & \\
\hline $0.430843 \mathrm{i}$ & & 0.825509 \\
\hline 0.787025 & & 0.787025 \\
\hline 0.693605 & \pm & 0.778167 \\
\hline $0.352784 \mathrm{i}$ & & \\
\hline-0.759332 & & 0.759332 \\
\hline-0.663914 & & 0.663914 \\
\hline
\end{tabular}

Source: Research Result Data (2019)

Based on Table 4.2, it can be seen that the stability test results are reasonably stable at lag 6 as the highest lag. Where is marked with modulus values that range between 0.663914-0.976316. These results indicate there is no modulus value that exceeds one, so it can be concluded that the model is stable at each selam length until the sixth lag.

\section{Determine The Optimum Lag}

The next step in estimating is to determine the optimum lag length. This determination is determined by looking at the results of Likehood
Ratio (LR), Final Prediction Error (FPE), Akaike Information Criterion (AIC), Schwarz Information Criterion (SC), and Hannan-Quin Criterion (HQ) marked with a star symbol $(*)$. This test is tested with a stable lag range from the stability results that have been tested before, namely lag 6 . Where the optimum lag is determined by seeing which lag has the most asterisks which are then chosen for estimation at the next stage. The following is the optimum lag test results using the $\mathrm{E}$ Views 8.0 application:

Table 4.3 Determine The Optimum

\begin{tabular}{|c|c|c|c|c|c|}
\hline Lag & LR & FPE & AIC & SC & HQ \\
\hline 0 & NA & $6.86 \mathrm{e}-06$ & 2.300130 & 2.504921 & 2.375650 \\
\hline 1 & 93.77982 & $1.76 \mathrm{e}-06$ & 0.928331 & 2.157075 & 1.381454 \\
\hline 2 & $\begin{array}{l}71.05537 \\
*\end{array}$ & $6.41 \mathrm{e}-07^{*}$ & -0.129359 & $2.123339^{*}$ & 0.701367 \\
\hline 3 & 25.36297 & $9.12 \mathrm{e}-07$ & 0.094063 & 3.370714 & 1.302391 \\
\hline 4 & 25.49960 & $1.20 \mathrm{e}-06$ & 0.097781 & 4.398386 & 1.683711 \\
\hline 5 & 30.27291 & $1.07 \mathrm{e}-06$ & -0.520188 & 4.804371 & 1.443345 \\
\hline 6 & 30.86814 & $6.59 \mathrm{e}-07$ & - & 4.418770 & 0.411393 \\
\hline
\end{tabular}

seen that the value containing an asterisk $\left({ }^{*}\right)$ is the smallest value contained in the criteria, so the lag at that value is the most optimum lag. In this test, the majority of the asterisks are in lag 2. Therefore, the most optimum lag for this research model is lag two. Which means that all the variables in this model affect each other not only in the current period, but up to the previous 2 periods.

\section{Cointegration Test}

Cointegration important to see the long-term balance between the observed variables. ${ }^{42}$ In addition, cointegration

\footnotetext{
${ }^{42}$ Sembiring, M. 2014. Analisis Vestor Autoregression (VAR) Terhadap
} 
40 IQTISHODUNA: Jurnal Ekonomi Islam Volume 9 Issue 1, April 2020

tests were also conducted to see the long-term relationship of the variables used in the study. An equation is said to have a cointegration relationship if the value of the trace statistic is greater than the value of its critical values. Following are the results of the Johansen Cointegration test on the EViews 8.0 application:

Table 4.1 Cointegration Test Results

\begin{tabular}{lll}
\hline $\begin{array}{l}\text { Hypothesized } \\
\text { No. Of CE (s) }\end{array}$ & $\begin{array}{l}\text { Trace } \\
\text { Statistic }\end{array}$ & $\begin{array}{l}\mathbf{0 , 0 5} \\
\text { Critical } \\
\text { Value }\end{array}$ \\
\hline None $^{*}$ & 162.0830 & 69.81889 \\
At most 1 & 110.9871 & 47.85613 \\
At most 2* & 71.70207 & 29.79707 \\
At most 3* & 42.44889 & 15.49471 \\
At most 4* & 19.77246 & 3.841466 \\
\hline
\end{tabular}

Source: Research Result Data (2019)

Based on Table 4.3, it can be seen that the Johansen cointegration test results show that there is a cointegration model, because it shows trace statistic and max eigen statistic values that are greater than $5 \%$ critical values. This indicates that the Model has a long and short term relationship so that it is continued by using the Vector Error Correction Model (VECM) test.

\section{Engel-Granger Causality Tes}

After getting the optimum and stable lag model, the Engel-Granger causality test is then performed to see the causality relationship between the variables in the model (Firdaus, 2011). Granger's approach to causality here is in a statistical framework, not based on concepts in

Interrelationship Antara IPM dan Pertumbuhan Ekonomi di Sumatera Utara. 1-10. a philosophical sense. So causality here refers to the concept of prediction (Ekananda, 2015). Following are the results of the Engel-Granger Causality test on the EViews 8.0 application:

\section{Table 4.2 Causality Test Results}

\begin{tabular}{|c|c|c|c|}
\hline Null Hyphotesis & $\begin{array}{l}F- \\
\text { statis } \\
\text { tic }\end{array}$ & Prob. & $\begin{array}{l}\text { Relatio } \\
\text { nship } \\
\text { Predict } \\
\text { ion }\end{array}$ \\
\hline $\begin{array}{l}\text { Stability is influenced } \\
\text { by IHK }\end{array}$ & $\begin{array}{l}0.2776 \\
7\end{array}$ & $\begin{array}{l}0.758 \\
9\end{array}$ & $\begin{array}{l}\text { Not } \\
\text { signific } \\
\text { ant }\end{array}$ \\
\hline $\begin{array}{l}\text { Stability is influenced } \\
\text { by KURS }\end{array}$ & $\begin{array}{l}0.8471 \\
2\end{array}$ & $\begin{array}{l}0.435 \\
5\end{array}$ & $\begin{array}{l}\text { Not } \\
\text { signific } \\
\text { ant }\end{array}$ \\
\hline $\begin{array}{l}\text { Stability is influenced } \\
\text { by CAR }\end{array}$ & $\begin{array}{l}0.0788 \\
7\end{array}$ & $\begin{array}{l}0.924 \\
3\end{array}$ & $\begin{array}{l}\text { Not } \\
\text { signific } \\
\text { ant }\end{array}$ \\
\hline $\begin{array}{l}\text { Stability is influenced } \\
\text { by NPF }\end{array}$ & $\begin{array}{l}1.1024 \\
6\end{array}$ & $\begin{array}{l}0.341 \\
1\end{array}$ & $\begin{array}{l}\text { Not } \\
\text { signific } \\
\text { ant }\end{array}$ \\
\hline $\begin{array}{l}\text { CAR is influenced by } \\
\text { stability } \\
\text { CAR is influenced by } \\
\text { NPF }\end{array}$ & $\begin{array}{l}10.673 \\
7 \\
4.5082 \\
8\end{array}$ & $\begin{array}{l}0.000 \\
2 \\
0.016 \\
6\end{array}$ & $\begin{array}{l}\text { Signific } \\
\text { ant } \\
\text { Signific } \\
\text { ant }\end{array}$ \\
\hline
\end{tabular}

Source: Research Result Data (2019)

Based on Table 4.4, the results obtained indicate that at a level of five percent, namely when the probability value is below 0.05 , it is predicted that there are no independent variables that significantly influence the stability in the study period. However, it turns out that there is a predicted relationship that significantly influences each other in the study period, namely between Stability to CAR and NPF to CAR. This result is in line with the results of the study ${ }^{43}$, which states that NPF has a significant negative effect on CAR, where each one percent increase in

\footnotetext{
${ }^{43}$ Andhika, Y. D., \& Suprayogi, N.
} 2017. Faktor-faktor yang Mempengaruhi Capital Adequacy Ratio (CAR) Bank Umum Syariah di Indonesia. Jurnal Ekonomi Syariah Teori dan Terapan Vol.4 No.4, 312-323. 
NPF will decrease CAR by 0.62 percent. The high NPF will increase the amount of Allowance for Earning Asset Losses (PPAP) which will eventually erode the capital of the bank concerned.

\section{Vector Error Correction Model (VECM) Test}

The Vector Error Correction (VECM) model is a VAR model that predicts the long-term behavior of endogenous variables to the cointegration relationships of other variables that allow for the dynamics of short-term adjustment (Ichsan \& Akhiroh, 2017). The VECM model has proven to be very useful for describing the dynamic behavior of economic and financial time-series data forms and also for forecasting. This model can provide estimates of influence in the short term as well as long term.

This study uses significance with a critical value of $5 \%$ with the number of study periods (n) 51, so the t-statistic value is \pm 1.67866 . Variables are declared to have a significant effect if they reject $\mathrm{HO}$ or accept H1, which is when the $t$ statistic value is> 1.67866 and <1.67866. Significant means that the tested variable influences the stability of the sample used, namely in January 2015 to March 2019. Conversely, it is not significant, meaning that the variable tested has no effect on inflation on the sample used. Following are the results of testing the VECM estimation using the EViews 8.0 application:
Table 4.3 VECM Test Results

\begin{tabular}{llll}
\hline Long Term & & & \\
\hline Variable & Coefficient & T-Statistics & Conclusion \\
\hline Stabilitas & 1.000000 & - & - \\
IHK & -11.92081 & -5.14758 & Significant \\
KURS & 374.6452 & 6.17997 & Significant \\
CAR & -1.811945 & -0.82970 & Not Significant \\
NPF & 4.792974 & 0.86792 & Not Significant \\
C & -0.290809 & - & - \\
\hline Short Term & & & \\
\hline Variable & Coefficient & T-Statistics & Conclusion \\
\hline Stability $(-1)$ & -1.045002 & -6.84528 & Significant \\
IHK (-1) & 0.066005 & 0.76736 & Not Significant \\
KURS (-1) & -6.023534 & -2.07475 & Significant \\
CAR (-1) & -0.103522 & -2.22179 & Significant \\
NPF $(-1)$ & 0.038600 & -1.06809 & Not Significant \\
Stability (-2) & -0.539032 & -3.92568 & Significant \\
IHK (-2) & -0.041747 & -0.58648 & Not Significant \\
KURS (-2) & -2.952210 & -1.79681 & Significant \\
CAR (-2) & 0.038600 & 0.74574 & Not Significant \\
NPF $(-2)$ & 0.103910 & 1.54426 & Not Significant \\
C & -0.001234 & -0.03178 & Not Significant \\
R-Square & 0.861859 & & Significant \\
Adj. & & & Significant \\
Square & 0.817167 & & \\
\hline \multicolumn{1}{c}{ Source: } & Research ReSult & & \\
\hline
\end{tabular}

Source: Research Result Data (2019)

Based on Table 4.5, it can be seen that in the long run the significant effect on stability is the CPI and KURS variables, with the direction of the CPI relationship having a negative effect, while KURS has a positive effect. Meanwhile, the CAR and NPF variables in the long run have no significant effect on stability. Meanwhile, in the short term the significant effect on stability is stability in one and two previous periods, the exchange rate in one and two previous periods and CAR in one previous period.

R-squared coefficient values and Adj. R-squared in this study is quite large, that is 0.861859 and 0.817167 which means that $86.20 \%$ or $81.72 \%$ stability variables can be explained by the IHK, KURS, CAR and NPF variables in January 2015 to March 2019. While $3.80 \%$ or $8.28 \%$ influence the stability January 2015 to March 2019 can be explained by other variables outside this research model. 
42 IQTISHODUNA: Jurnal Ekonomi Islam Volume 9 Issue 1, April 2020

Inflation Influence of Stability

From the study of theory and research results in the framework that has been presented in chapter 2 , a hypothesis is drawn that inflation has a negative relationship to stability, some that are significant and some that are not. The difference in results occurs because of differences in the time period in seeing the effect of inflation. Based on the results of the causality test in table 4.5, it is obtained that the probability of inflation is more than 0.05, which indicates that the inflation prediction has no significant effect on stability.

More clearly, based on the results of the VECM analysis in table 4.6 the effect of inflation in the short term was not significant with a different direction of relationship, in the previous period it was positive while in the two previous periods it was negative. Influence of inflation on banking stability in the short term is caused by inflation rates that tend not to experience major changes in the short term. In addition, in the short term, new inflation usually affects the price sector in transactions between consumers and producers. When there is inflation, prices continue to rise, then the purchasing power of the people will decrease because the value of money continues to be eroded by inflation which causes an increase in production costs to the detriment of producers. Producers are reluctant to continue their production, and producers can stop their production for a while so that it will only affect producers and consumers. ${ }^{44}$

The inflation relationship in the short term can be positive and negative based on the fact that inflation at a certain level (below the treshold value) has the positive influence needed to encourage economic growth, for example in the short run inflation can be beneficial for producers because it will increase the price level so that at finally the producer will increase the amount of production. 45 However, negative consequences occur when the inflation rate is high and uncontrollable so that it interferes with banking efforts in mobilizing public funds. High inflation rates cause real interest rates to decline. This fact will reduce the public's desire to save so that the growth of banking funds sourced from the public will decline. ${ }^{46}$

While the VECM results in the long run show that inflation has a significant negative effect on stability with a coefficient value of -11.92081 , which indicates that every increase in inflation by one percent will have an impact on a decrease in the stability level of $11.92 \%$. The results of this study are in line with the results of research from Altaee, Talo, \& Adam ${ }^{47}$, Alfiana, Widayatun, and Sianipar, ${ }^{48}$ Pujianti \& Sitorus ${ }^{49}$, Safitri

\footnotetext{
${ }^{44}$ Safitri, etc. Ibid.

${ }^{45}$ Ichsan, etc. Ibid.

${ }^{46}$ Dwijayanthi, etc. Ibid

${ }^{47}$ Altaee, etc. Ibid.

${ }^{48}$ Alfiana, etc. Ibid.

${ }^{49}$ Pujianti, R., \& Sitorus., N. H. 2016.

Analisis Struktur Pasar Perbankan dan Stabilitas Perbankan Di Indonesia. Jurnal Ekonomi Pembangunan, Vol.5, No.2, 217-238.
} 
$\mathrm{TR}^{50}$, Rahim \& Zakaria ${ }^{51}$ and Yudaruddin ${ }^{52}$ which states that inflation has a significant negative effect on stability. But contrary to the results of research conducted by Wahid and Dar which states that inflation has a negative and not significant effect on stability. 53

Banking stability in general is reflected in a healthy banking condition or free from financial distress in the sense that banks can carry out their intermediary functions properly in raising funds and then mobilizing public deposits to be channeled in the form of financing to the business world such as the MSME sector. ${ }^{54}$ In this case inflation is possible to influence the ability of banks to carry out their functions as intermediary institutions for surplus and deficit funds in terms of increasing third party funds (DPK) and financing. ${ }^{55}$

When inflation rises, Islamic banking is faced with two problems (Yudaruddin, 2014). First, from the side of the collection of Third Party Funds (DPK) will decrease because deposit rates will increase, so that deposit rates in conventional banking are higher and more attractive to customers than returns on Islamic banking. ${ }^{56}$ Second, in terms of financing. For the business world, as a producer of goods and services, inflation can be beneficial if

\footnotetext{
${ }^{50}$ Safitri, etc. Ibid.

${ }^{51}$ Rahim, etc. Ibid.

${ }^{52}$ Yudaruddin, Ibid.

${ }^{53}$ Wahid, etc. Ibid.

${ }^{54}$ Alfiana, etc. Ibid.

55Ichsan, etc. Ibid.

${ }^{56}$ Elsa, etc. Ibid
}

the income earned is higher than the increase in production because producers will be compelled to double their production. However, if inflation causes production costs to rise, producers are reluctant to continue production, which will have an impact on their declining financial performance..$^{57}$

Thus, the results of this study accept the hypothesis of a negative relationship between inflation and stability. The complete results of this study state that the relationship between inflation and stability over the period of January 2015 to March 2019 in the positive and negative short term is not significant, whereas in the long term negative is significant. This indicates that when the inflation rate has increased in the long run, it will have an impact on the decline in the level of stability of Islamic banks.

\section{Exchange rate (KURS) Influence of Stabilty}

From the study of theory and research results in the framework that has been presented in chapter 2, a hypothesis is drawn that exchange rates have a negative relationship to stability, some that are significant and some that are not. The difference in results occurs because of differences in the time period in seeing the effect of the exchange rate. Based on the results of the causality test in table 4.5 , the probability value of the exchange rate is more than 0.05 , which indicates that the 
prediction of the exchange rate has no significant effect on stability.

More clearly, based on the results of the VECM analysis in table 4.6 the effect of exchange rates in the short term in one and two periods was negative and significant, with each coefficient of -6.023534 and 2.952210. This indicates that in the short term, each increase in the exchange rate of 1000 rupiah (adjusting data processing using a loan), there will be a decrease in the stability level of $2.95 \%$ to $6.02 \%$. The results of this study are in line with the results of research from (Alfiana, Widayatun, and Sianipar ${ }^{58}$, Safitri T. R.59, and Yudaruddin ${ }^{60}$ which states that the exchange rate has a significant negative effect on stability.

The effect of the exchange rate on this significant stability is believed to be reasonable because the real exchange rate is an early warning indicator of the banking and currency crisis. 61 Where fluctuations in the rupiah exchange rate greatly affect the stability of banking stability because when the exchange rate falls or weakens it will affect the increase in the NPF which will then cause a liquidity crisis in the Islamic banking industry. Exchange rates from year to year that continue to experience fluctuations will affect the ability of banks to increase third party funds because people tend to want to have foreign currencies so that withdrawing

\footnotetext{
${ }^{58}$ Alfiana, etc. Ibid.

${ }^{59}$ Safitri, etc. Ibid.

${ }^{60}$ Yudaruddin. Ibid

${ }^{61}$ Alfiana, etc. Ibid.
}

funds from banks will then affect the ability of banks to carry out their functions as an intermediary institution, i.e. distribution of financing. ${ }^{62}$

While in the long term the exchange rate has a significant positive effect on stability with a coefficient of 374.6452, indicating that every time an exchange rate increases by 1000 rupiahs, it will have an impact on increasing the stability level of $374.65 \%$. This can occur because the foreign exchange rate is one of the factors of bank profitability, because in its activities the bank provides foreign exchange trading services. Under normal circumstances, trading foreign exchange is basically very profitable because the transaction produces profits in the form of foreign exchange differences. This happens because foreign exchange traders always offer two exchange rates. In these transactions, the exchange rate for foreign currencies is of concern to the bank because it can influence the level of profitability of the bank. With fluctuations in foreign exchange rates, banks can obtain income in the form of fees and foreign exchange difference. ${ }^{63}$

Thus, the results of this study accept the hypothesis of a negative relationship between exchange rates and stability. The complete results of this study state that the relationship between the exchange rate and stability over the period of January 2015 to March 2019 in the short term is significantly negative, whereas in

${ }^{62}$ Ichsan, etc. Ibid.

${ }^{63}$ Dwijayanthy. Ibid. 
the long run it is significantly positive. This indicates that when the exchange rate increases in the short term, it will have an impact on the decrease in the level of stability and vice versa.

\section{CAR Influence of Stability}

From the study of theory and research results in the framework that has been presented in chapter 2, a hypothesis is drawn that CAR has a positive relationship with stability, some that are significant and some that are not. The difference in results occurred because of differences in the time period in seeing the effect of the CAR. Based on the results of the causality test in table 4.5 , it is obtained that the probability of inflation is more than 0.05, which indicates that the predicted CAR has no significant effect on stability.

More clearly, based on the results of the VECM analysis in table 4.6 the effect of CAR in the short term in one previous period was significantly negative, whereas in the two previous periods it was positive not significant. The result of this two-way influence shows that CAR is one of the possible sources of financial instability, which on the one hand can have a good impact and one side can have a negative impact for a financial stability including Islamic banking. In this case CAR has a positive impact when the increase is accompanied by an increase in total financing, a decrease in NPF, and an increase in profitability. Whereas CAR had a negative impact when the increase was not offset by increased distribution of funding and profitability, but in line with the increase in NPF. 64

Whereas in the long term, CAR has a significant negative effect on stability with a coefficient value of 1.811945, which indicates that every time there is an increase in the CAR level by one percent, it does not have a significant impact on reducing the stability level of $1.81 \%$. Because the results of this study were found to be insignificant, the interpretation is still not strong enough to prove the negative relationship between CAR and stability. The results of this study contradict the results of research by Myirandasari which states that CAR has a positive influence on stability, where CAR is one of the main factors influencing the ability of Islamic banks in the expansion of office networks and the development of deposit interest rates. ${ }^{65}$ Which then has an impact on the performance of Islamic banks and their stability. ${ }^{66}$

Thus, the results of this study refuse the hypothesis of a positive relationship between CAR and stability. The complete results of this study state that the relationship between CAR and stability during the period of January 2015 to March 2019 in the short term in the previous period had a negative and significant effect, then the two previous periods had a non-significant positive effect. Whereas in the long run, the level of CAR has a negative and not significant effect on the level of stability. This indicates that when the

\footnotetext{
${ }^{64}$ Alfiana, etc. Ibid.

${ }^{65}$ Myirandasari., Ibid.

${ }^{66}$ Elsa, etc. Ibid.
} 
CAR level increases in the short term, it will have an impact on decreasing the level of stability.

\section{NPF Influence of Stability}

From the study of theory and research results in the framework that has been presented in chapter 2, a hypothesis is drawn that NPF has a negative relationship with stability, some states are significant and some are not. The difference in results occurs because of differences in the time period in seeing the effect of inflation. Based on the results of the causality test in table 4.5 , the NPF probability value is more than 0.05 , which indicates its prediction, NPF has no significant effect on stability.

More clearly, based on the results of the VECM analysis in table 4.6 the effect of NPF in the short term is positive and not significant. Similarly, in the long run, that the NPF has a positive and insignificant effect on stability with a coefficient of 4.792974, indicating that each increase in the NPF level by one percent does not have a significant impact on increasing the stability level of $4.79 \%$. The results of this study are in line with the results of research from Wahid, etc. which states that the NPF has a positive coefficient, this implies that the NPF does not contribute negatively to the stability of Islamic banks. However, this result was found to be insignificant so it needs to be understood carefully. ${ }^{67}$

NPF can have a positive effect on stability because NPF can have a positive effect on profitability,

${ }^{67}$ Wahid, etc. Ibid namely ROA of Islamic Commercial Banks. In this case, it means that the problematic financing arises because of the opportunity to get large profits from parties outside the customer and this is one of the great income alternatives for banks. The higher ratio shows that Islamic banking activities tend to benefit compared to the normal distribution of financing to its customers (high risk, high return). ${ }^{68}$

The insignificant influence of the NPF is based on the fact that the NPF is the directional impact of inflation on stability. Where inflation will cause a high risk of default, the NPF of Islamic banking. If the financing is based on profit sharing agreement, if the debtor experiences a business loss, this loss will also be borne by the Islamic bank (risk sharing). If the type of financing is a sale and purchase agreement (murabahah) then high inflation can make sharia financing products in general relatively more expensive (Ichsan \& Akhiroh, 2017).

Thus, the results of this study reject the hypothesis of a negative relationship between NPF and stability. Because the results of this study stated that the relationship between NPF and stability over the period of January 2015 to March 2019 both in the short and long term was positive and not significant. This indicates that when the NPF level has increased in the short and long

${ }^{68}$ Diknawati, D. A. 2014. Analisis Pengaruh CAR, NPF, FDR dan BOPO Terhadap Profitabilitas Bank Umum Syariah. 1-15. 
The Influence of Inflation, Exchange Rates, Car And Npf To

Stability of Islamic Banks In Indonesia Period 2015-2019

term, it does not significantly affect the level of stability.

\section{Impulse Response Function (IRF) Test}

After the VECM estimation test is carried out, a method is needed to clearly describe the dynamic structure of VECM. ImpulseResponse Function (IRF) is used to identify a shock on one endogenous variable so that it can determine how an unexpected change in a variable affects another variable.

IRF shows the long-term dynamic response to each variable due to certain shocks in each equation. The horizontal axis represents the time in the period of the day after the shock while the vertical source is the response value. Basically, in this analysis we will know that a variable has a positive or negative response to other variables. The response in the short term is usually quite significant and tends to change, whereas in the long term the response tends to be consistent and continue to shrink.

IRF explains the response to changes in the level of stability due to shocks from the stability level variable itself, and inflation, exchange rate, CAR and NPF variables over the next 10 periods so that the changes are more visible. Following are the results of IRF testing using the EViews 8.0 application:

\section{Table 4.4 IRF Test Results}

\begin{tabular}{lcrrrr}
\hline $\begin{array}{l}\text { Period } \\
\text { (Month) }\end{array}$ & Stability & \multicolumn{1}{l}{ IHK } & \multicolumn{1}{c}{ KURS } & \multicolumn{1}{c}{ CAR } & \multicolumn{1}{l}{ NPF } \\
\hline 1 & 0.2039 & 0.0000 & 0.0000 & 0.0000 & 0.0000 \\
2 & -0.1624 & -0.0185 & -0.0152 & -0.0922 & 0.0171 \\
3 & 0.0467 & -0.0010 & 0.0295 & 0.1598 & 0.0122 \\
4 & 0.0267 & 0.0216 & -0.0320 & -0.1275 & -0.0422
\end{tabular}

\begin{tabular}{lrrrrr}
5 & -0.0410 & -0.0220 & 0.0104 & 0.0247 & 0.0336 \\
6 & 0.0234 & 0.0237 & 0.0105 & 0.0565 & -0.0006 \\
7 & -0.0021 & -0.0156 & -0.0155 & -0.0657 & -0.0207 \\
8 & -0.0071 & -0.0019 & 0.0145 & 0.0259 & 0.0156 \\
9 & 0.0046 & 0.0106 & -0.0143 & 0.0134 & 0.0027 \\
10 & $5.6 \mathrm{E}-1$ & -0.0034 & 0.0087 & -0.0254 & -0.0138 \\
\hline \multicolumn{5}{c}{ Source. } \\
\end{tabular}

Based on Table 4.6, it can be seen that the stability level shock of one standard deviation in period 1 achieved a response of around $0.20 \%$ level of stability. However, shocks to the Inflation, KURS, CAR and NPF levels of one standard deviation in period 1 have not yet received a response because stability is still fully influenced by itself in the previous period.

Starting from period 1 to period 2 , it can be seen that shocks to the level of stability responded negatively (decreased) by the level of stability itself to $0.16 \%$, which then responded back positively (increased) in period 3. While towards period 2 the rate of inflation responded negatively (decreased ) by $0.01 \%$ up to period 3. After that in period 4 the response changed to positive (increased) by $0.02 \%$.

Meanwhile, towards period 2 the exchange rate was responded to negatively (decreased) by $0.02 \%$. After that in period 3 the response changed to positive (increased) by $0.03 \%$. Similarly, the level of CAR that responded negatively (decreased) by $0.09 \%$. After that in period 3 the response changed to positive (increased) by $0.16 \%$. In contrast to the level of NPF that responded positively (increased) by $0.02 \%$. After that in period 3 the response changed to negative (decreased) until period 4 respectively $0.01 \%$ and $0.04 \%$. 
In the end the response of the stability level from the shock of the stability level, inflation, KURS, CAR and NPF continues to change to increase and decrease (fluctuate) until the 10th period. From the exposure it can be concluded that within 10 months, stability has not recovered from the stability, inflation, KURS, CAR and NPF.

\section{Forecast Error Variance Decomposition (FEVD) Test}

The next step is to analyze the Forecasting Error of Variance Decomposition (FEVD) which is used to analyze how much the shock of a variable affects other variables (Sembiring, 2014). FEVD aims to predict the percentage contribution of each variable due to changes in certain variables in the system. If IRF analysis is used to see the impact of shocks from one variable on another, the FEVD analysis is used to illustrate the relative importance of each variable in the system due to shock (Juanda \& Junaidi, 2012). If the order of magnitude of a variable is wider (far from the equilibrium point), then the stronger the variable responds to the shock of changes in other variables, and vice versa. ${ }^{69}$

The FEVD results show that in the first period the variability and fluctuation of values of the stability variable can be explained $100 \%$ by the variable itself. The influence given by other variables began to be seen in the second period, where the

\footnotetext{
${ }^{69}$ Natsir, M. 2008. Peranan Jalur Suku Bunga dalam Mekanisme Transmisi Kebijakan Moneter di Indonesia. Pustaka Pascasarjana Unhalu Kendari, 1-12.
}

effect of the stability variable itself reduced to $87.89 \%$. CAR variable gives the biggest influence, with the amount of influence of $10.99 \%$, then followed by the CPI variable that has an effect of $0.44 \%$, the NPF variable that has an effect of $0.38 \%$ and the KURS variable which has an effect of $0.30 \%$.

The stability variable until the end of the period is the most influential variable on the change in stability itself with the contribution amount at the end of the period reaching $50.90 \%$. Then followed by CAR variable which since the second period consistently has the biggest influence so that at the end of the period it has an effect of $41.90 \%$. Thirdly, the NPF variable experiences a continuously increasing influence each period following the magnitude of the CPI effect, so that at the end of the period it has an effect of $3.10 \%$. Meanwhile, the CPI variable that initially experienced the largest upward trend in the second period only consistently rose with a small magnitude, so that at the end of the period the smallest contribution was accounted for only $1.73 \%$.

\section{CONCLUSION}

Based on the results of research and discussion in the previous chapter, the conclusions of this study can be explained as follows:

In the short term, the inflation rate has no effect on stability, both in one previous period and the two previous periods. This happens because in the short term the amount of inflation has not changed much 
and has only been felt on the impact of prices at the producer and consumer levels. Meanwhile in the long term, the inflation rate has a significant negative effect on the level of stability. This indicates that when the inflation rate increases in the long term, it will have an impact on decreasing the level of stability. This significant negative effect occurs because in the long term, uncontrolled inflation will lead to financial distress of financial institutions where the intermediary function as a collector and distributor of funds is disrupted, so performance and stability also decline.

In the short term, the exchange rate (kurs) in the previous one and two periods has a significant negative effect on the level of stability. Whereas in the long term, the exchange rate (kurs) has a significant positive effect on the level of stability. This indicates that when the exchange rate (kurs) increases in the short term, it will have an impact on the decrease in the level of stability and vice versa. Significant influence of the exchange rate (kurs) in both the short and long term occurs because the real exchange rate (kurs) is an early warning indicator of the banking and currency crisis which affects the ability of banks to increase third party funds which continues to disrupt the disbursement of funds.

In the short term in the previous two periods and in the long term CAR has no effect on stability. Meanwhile, the CAR in the short term in the previous period had a significant negative effect on the level of stability. This indicates that when the CAR level increases in the short term, it will have an impact on decreasing the level of stability. Significance of CAR in the previous one period could occur because of coupled with disruptions in banking functions such as decreasing deposits, decreasing levels of fund distribution, decreasing profitability, but increasing NPF, so that stability in the functions was even disturbed.

In the short term, the NPF level in the previous one and two periods did not affect the level of stability. Similarly, in the long term, the NPF level does not affect the level of stability. This indicates that NPF has no influence on the level of stability in the short or long term. The insignificant influence of the NPF is based on the fact that the NPF is the directional impact of inflation on stability (not a direct effect). Where inflation will cause a high risk of default is the Islamic banking NPF which is then passed on to banking instability.

\section{REFERENCES}

Abdullah, B. 2012. Perkembangan Ekonomi Islam di Indonesia Melalui Sistem Perbankan Syariah. 'Adliya: Jurnal Hukum dan Kemanusiaan, Vol.VI, No.3, 65-74.

Abidin, Z. 2010. Transaksi Mata Uang dalam Pandangan Islam. al-Ihkam Vol.V No.1, 127-144.

Alfiana, Widayatun, V. W., \& Sianipar., A. S. 2016. 
50 IQTISHODUNA: Jurnal Ekonomi Islam Volume 9 Issue 1, April 2020

Determinan Faktor-faktor yang Mempengaruhi Ketidakstabilan Keuangan di Indonesia. Widyatama, 1-30.

Altaee, H. H., Talo, I. M., \& Adam., M. H. 2013. Testing the Financial Stability of Banks in GCC Countries: Pre and Post Financial Crisis. International Journal of Business and Social Research (IJBSR), Vol.3, No.4, 93105.

Amin, R., Rafsanjani, H., \& Mujib, A. 2017. Faktor-Faktor Yang Mempengaruhi Non Performing FInancing: Studi Kasus Pada Bank BPR Syariah di Indonesia. Jurnal Masharif alSyariah: Jurnal Ekonomi dan Perbankan Syariah, 1-19.

Andhika, Y. D., \& Suprayogi, N. 2017. Faktor-faktor yang Mempengaruhi Capital Adequacy Ratio (CAR) Bank Umum Syariah di Indonesia. Jurnal Ekonomi Syariah Teori dan Terapan Vol.4 No.4, 312-323.

Antonio, M. S. 2001. Bank Syariah: Dari Teori ke Praktik. Jakarta: Gema Insani Press.

Asfari, D. D. 2015. Analisis Financial Stress Indikator Sebagai Alat Ukur Stabilitas Sektor Keuangan Indonesia. Jurnal Bina Ekonomi Vol.19 No.1, 15-25.

Bank Indonesia. 2018, November 16. Penguatan Ketahanan Stabilitas Sistem Keuangan Mendorong Momentum Pertumbuhan.
Kajian Stabilitas Keuangan No.31, September 2018, pp. 1-174.

Basuki, A. T. 2018. Bahan Ajar: Aplikasi Model VAR dan VECM Dalam Ekonomi. Retrieved from EkonometrikBlog: ekonometrikblog.wordpress.co $\mathrm{m}$

Basuki, A. T., \& Yusuf, A. I. 2018. Aplikasi Model VECM Dalam Riset Ekonomi. Retrieved from ekonometrikblog.wordpress.co $\mathrm{m} /$ page/2/

Beik, I. S., \& Fatmawati, S. W. 2014. Pengaruh Indeks Harga Saham Syariah Internasional dan Variabel Makro Ekonomi Terhadap Jakarta Islamic Indeks. Al-Iqtishad, 155-178.

Bombang, S. 2013. Prospek Perbankan Syariah di Indonesia. Jurnal Diskursus Islam Vol.1 No.2, 265-288.

Dian, A. 2016. Dasar Hukum Bank Syariah: Undang-Undang dan AlQuran. Retrieved from DosenEkonomi.com: https://dosenekonomi.com/il mu-ekonomi/ekonomisyariah/dasar-hukum-banksyariah

Diknawati, D. A. 2014. Analisis Pengaruh CAR, NPF, FDR dan BOPO Terhadap Profitabilitas Bank Umum Syariah. 1-15.

Dwijayanthy, F., \& Naomi, P. 2009. Analisis Pengaruh Inflasi, BI Rate, dan Nilai Tukar Mata Uang terhadap Profitabilitas 
The Influence of Inflation, Exchange Rates, Car And Npf To

Stability of Islamic Banks In Indonesia Period 2015-2019

Bank Periode 2003-2007. Jurnal Karisma Vol. 3 No.2, 87-98.

Ekananda, M. 2014. Ekonomi Internasional. Jakarta: Erlangga.

Ekananda, M. 2015. Ekonometrika Dasar Untuk Penelitian di Bidang Ekonomi, Sosial dan Bisnis. Jakarta: Mitra Wacana Media.

Elsa, \& Utami., W. 2015. Studi Komparasi Efisiensi, Kualitas Aset dan Stabilitas pada Bank Umum Konvensional di Indonesia Periode 2010-2014. Jurnal Ilmu Ekonomi dan Sosial, Volume 4, Nomor 1, 104-114.

Firdaus. 2011. Aplikasi Ekonometrika untuk Data Panel dan Time Series. Bogor: IPB Press.

Fitri, M. 2015. Prinsip Kesyariahan Dalam Perbankan Syariah. Economica Vol.VI Edisi 1, 57-70.

Gifari, Handoko, \& Yani. 2015. Analisis Kinerja Perbankan Syariah di Indonesia dan Malaysia Dengan Pendekatan Maqashid Indeks. Jurnal Ekonomi dan Perbankan Syariah Vol.3 No.2, 47-66.

Gunadi, I., Taruna, A. A., \& Harun, C. A. 2015. Penggunaan Indeks Stabilitas Sistem Keuangan (ISSK) Dalam Pelaksanaan Surveilans Makroprudential. Working Paper Bank Indonesia, 155.

Hermawan, H. 2008. Sumber dan Penggunaan Dana Qarḍ dan Qarḍul Hasan pada Bank BRI
Syariah Cabang Yogyakarta. LaRiba : Jurnal Ekonomi Islam, Vol.II, No.2, 263-278.

Hidayatusholihah. 2016. Pemikiran Taqiyuddin An-Nabhani

Tentang Riba dalam Pertukaran Mata Uang. Jurnal Islamic Review (JIE) Vol.V No.1, 85-108.

Ichsan, N., \& Akhiroh, M. 2017. Analisis Pengaruh Ekonomi Makro dan Stabilitas Perbankan Syariah terhadap Pembiayaan Produktif dan Konsumtif pada Perbankan Syariah di Indonesia Periode Januari 2010-Maret 2017. Jurnal Akses Vol.12 No.23, 68-83.

Izazi, S. A., \& Waskito, A. 2014. Analisis Kompetisi Bank Umum Konvensiona dan Stabilitas Perbankan di Indonesia Periode 2004-2013: Sebuah Pendekatan Struktural dan Non Struktural. E-journal FE UI, 1-22.

Jiwandono, T. 2014. Analisis Faktor Fundamental terhadap Harga Saham Sektor Perbankan yang Go Public di Indeks Kompas 100. Jurnal Ilmu Manajemen Vol.1 No.2, 783-794.

Karim, A. 2015. Ekonomi Makro Islami. Jakarta: PT Raja Grafindo Persada.

Kuntjotjo. 2009. Metodologi Penelitian. Kediri: Ebekunt.

Latumaerissa, J. R. 2017. Bank Dan Lembaga Keuangan Lain : Teori 
52 IQTISHODUNA: Jurnal Ekonomi Islam Volume 9 Issue 1, April 2020

dan Kebijakan. Jakarta: Mitra Wacana Media.

Mulyaningsih, S., \& Fakhruddin, I. 2016. Pengaruh Non Performing Financing Pembiayaan Mudharabah dan Non Performing Financing Pembiayaan Musyarakah Terhadap Profabilitas Pada Bank Umum Syariah di Indonesia. Jurnal Manajemen dan Bisnis MEDIA EKONOMI Volume XVI, No.1, 196-206.

Munir, M. S. 2013. Analisis Perbandingan Kinerja Keuangan Perbankan Syariah dengan Perbankan Konvensional. e-Journal UNESA, 1-21.

Myirandasari., B. 2015. Analisis Komparasi Stabilitas Perbankan Syariah dan Konvensional (Bank Umum Devisa Non Go Public di Indonesia). Brawijaya, 1-20.

Nasution, J. 2016. Pemikiran Ekonomi Islam Seputar Sharf Menurut Taqiyuddin Alnabani. Jurnal At-Tijaroh Vol.2, No.2, 185-198.

Natsir, M. 2008. Peranan Jalur Suku Bunga dalam Mekanisme Transmisi Kebijakan Moneter di Indonesia. Pustaka Pascasarjana Unhalu Kendari, 112.

Noorani, A. I., Hermani, A., \& Saryadi. 2014. Pengaruh CAR, LDR, BOPO dan NPL Terhadap
Penyaluran Kredit. Diponegoro Journal of Social and Politik, 1-10.

Pujianti, R., \& Sitorus., N. H. 2016. Analisis Struktur Pasar Perbankan dan Stabilitas Perbankan Di Indonesia. Jurnal Ekonomi Pembangunan, Vol.5, No.2, 217-238.

Rachman, Y. T. 2015. Pengaruh Financing to Deposit Ratio (FDR), Non Performing Financing (NPF), Return On Assets (ROA), dan Capital Adequacy Ratio (CAR) terhadap Pembiayaan Mudharabah (Survey pada Bank Syariah yang Listing di Bursa Efek Indonesia pada Tahun 2009-2013). Proceedings ICIEF'15, Mataram, 1504-1521.

Rahardja, P., \& Manurung, M. 2004. Pengantar Ilmu Ekonomi: Mikroekonomi dan Makroekonomi. Jakarta: Fakultas Ekonomi Universitas Indonesia.

Rahim, S. R., \& Zakaria., R. H. 2013. Comparison on Stability Between Islamic and Conventional Banks in Malaysia. Journal of Islamic Economics, Banking and Finance, Vol.9 No.132, 131-149.

Rohmanda, D., Suhandak, \& Topowijono. 2014. Pengaruh Kurs Rupiah, Inflasi dan BI Rate terhadap Harga Saham (Studi pada Indeks Sektoral Bursa Efek Indonesia Periode 2005-2013). Jurnal Administrasi Bisnis (JAB) Vol.13 No.1, 1-10. 
Safitri, T. R. 2018. Analisis Pengaruh Fakor Makroekonomi dan Faktor Fundamental Terhadap Stabilitas Perbankan Konvensional di Indonesia Tahun 2008-2017. Jurnal Ilmiah Mahasiswa FEB UNIVERSITAS BRAWIJAYA Vol 6, No 2: Semester genap 2017/2018, 1-13.

Saleh, L. 2016. Perubahan Nilai Tukar Uang Menurut Perspektif Ekonomi Islam. Li Falah: Jurnal Studi Ekonomi dan Bisnis Islam Vol.1 No.1, 68-79.

Sembiring, M. 2014. Analisis Vestor Autoregression (VAR) Terhadap Interrelationship Antara IPM dan Pertumbuhan Ekonomi di Sumatera Utara. 110.

Silalahi, U. 2012. Metode Penelitian Sosial. Bandung: Refika Aditama.

Sitepu, N. I. 2015. Peran Bank Syariah dalam Pengendalian Harga (Studi Analisis Terhadap Perbankan Syariah di Indonesia). Jurnal Perspektif Ekonomi Darussalam Vol.1 No.1, 55-74.

Solihatun. 2014. Analisis Non Performing FInancing (NPF) Bank Umum Syariah di Indonesia Tahun 2007 - 2012. Jurnal Ekonomi Pembangunan, Vol 12 No.1 Juni 2014, 58-68.

Suhartono. 2009. Peran Bank Sentral dalam Stabiitas Sistem Keuangan (SSK) dan
Implementasi Jaring Pengaman Sektor Keuangan (JPSK). Jurnal Keuangan dan Perbankan, Vol. 13, No.3, 518-533.

Supriyanto, T. 2015. Konsep Rate of Profit dan Stabilitas Ekonomi Perbankan Syariah. Jurnal Etikonomi Vol.14 No.2, 175- 204.

Suryana. 2010. Metodologi Penelitian: Model Praktis Penelitian Kuantitatif dan Kualitatif. Bandung: Universitas Udayana.

TafsirQ. 2019. Retrieved from TafsirQ: https://tafsirq.com/4an-nisa/ayat-29

Vanni, K. M., \& Rokhman, W. 2017. Analisis Faktor-Faktor Yang Mempengaruhi Non Performing Financing Pada Perbankan Syariah Di Indonesia Tahun 2011-2016. EQUILIBRIUM: Jurnal Ekonomi Syariah Volume 5, Nomor 2, 306319.

Wahid, M. A., \& Dar., H. 2016. Stability of Islamic versus Conventional Banks: A Malaysian Case. Jurnal Ekonomi Malaysia 50 (1), 111-132.

Wibowo, B. 2016. Stabilitas Bank, Tingkat Persaingan Antar Bank dan Diversifikasi Sumber Pendapatan: Analisis Per Kelompok Bank di Indonesia. Jurnal Manajemen Teknologi Vol.15 No.2, 172-195. 
54 IQTISHODUNA: Jurnal Ekonomi Islam Volume 9 Issue 1, April 2020

Yudaruddin, R. 2014. Dampak

Tingkat Konsentrasi terhadap Kinerja dan Stabilitas

Perbankan di Indonesia Tahun 2003-2013. Jurnal Keuangan dan Perbankan Vol.18 No.2, 278-286.

Yusuf, M., \& Sari, R. K. 2013. Analisis Faktor-faktor yang Mempengaruhi Tingkat Perolehan Margin Dengan Akad Murabahah Pada Bank Syariah X. Binus Business Review Vol. 4 No. 2, 687-696. 